\author{
Л.С. Болгова, Т.М. Туганова, О.І. Алексєєнк, Т.М. Ярощук, М.Г. Махортова, С.О. Логінова, \\ С.В. Мариненко, Г.О. Супрун, Н.В. Богоніс
}

\title{
Можливості ексфоліативної цитологічної діагностики залежно від характеру росту раку легені
}

\author{
Національний інститут раку, Киӥв \\ Одержано 18.11.2021 \\ Прийнято до друку 2.12.2021 \\ DOI: 10.32471/clinicaloncology.2663-466X.43-3.28332
}

\begin{abstract}
Вступ. Рак легені (РЛ) - онкологічне захворювання, яке у світі виявляють найчастіше. Зберігається і висока смертність від нього. Лікування пацієнтів з РЛ починається тільки після морфологічної верифікації (цитологічної чи гістологічної). Першим етапом на шляху уточнення характеру патологічного процесу в легені $\epsilon$ цитологічне дослідження матеріалу (мазки і промивні води бронха), отриманого при виконанні фібробронхоскопії. Мета-визначити результати цитологічної діагностики за ексфоліативними матеріалами з бронхів. Матеріали і методи. Виконаний аналіз результатів цитологічної діагностики за матеріалами, отриманими при ФБС у 776 пацієнтів, які обстежувалися і лікувалися в Національному інституті раку у 2016 р. Середній вік

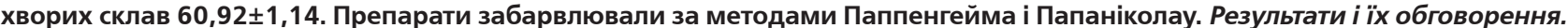
Установлено гістологічний тип РЛ у 195 пацієнтів (25\%), у 24 (3,5\%)- у висновку зазначена підозра на РЛ, у 35 (4,5\%) хворих видано описову відповідь. Найбільшу групу становили 522 (67\%) пацієнти, у цитологічних препаратах яких виявлено тільки циліндричний епітелій слизової оболонки бронха. Цей факт обґрунтував необхідність співставити отримані дані з результатами операційного матеріалу (проведені зскрібки з поверхні екзофітних пухлин у бронхах). При цьому виявлено ракові клітини у 9 (28\%) з 31 хворого, у решти - 22 (72\%) - тільки клітини циліндричного епітелію. Висновки. До цього часу в спеціальній літературі не було опубліковано інформацію про встановлений нами факт залежності результатів ексфоліативної цитологічної діагностики від проростання РЛ слизової оболонки бронха. Результати проведеного дослідження дозволяють стверджувати, що ексфоліативна цитологічна діагностика РЛ можлива у 28-33\% спостережень і залежить від ступеня проростання раковою пухлиною слизової оболонки бронха. Виявлений ріст РЛ під слизовою оболонкою бронха має пряме відношення до подальшого вивчення гістогенезу РЛ, що є важливим напрямком у перспективному розвитку фундаментальної і прикладної онкоморфології і онкопульмонології.
\end{abstract}

Ключові слова: ріст раку легені; ексфоліативна цитологічна діагностика.

\section{ВСТУП}

Рак легень (РЛ) - онкологічне захворювання, яке у світі відмічають найбільш часто [1]. Так, у 2020 р. на РЛ захворіло більше 19 млн осіб, що становило 11,4\% усіх онкологічних процесів, а померло близько 10 млн (18\%) [1]. В Україні, за уточненими даними, у 2019 р. захворюваність на РЛ у чоловіків становила 66,6, а смертність - 50,3 на 100 тис. населення [2].

Приведена статистика свідчить про необхідність поглибленого вивчення питань етіології, росту, діагностики і лікування РЛ та інших аспектів, які могли б прискорити їх вирішення, а відтак знизити захворюваність і підвищити ефективність лікування

В онкологічній практиці лікування хворих можна починати тільки після верифікації патологічного процесу морфологічними методами (цитологічним чи гістологічним).

Комплексне обстеження перед початком терапії РЛ включає цитологічне дослідження, яке займає провідне місце і є першим етапом морфологічної діагностики РЛ, а у разі розповсюдженого процесу часто стає єдиним [3, 4]. При цьому його використання $є$ найбільш простим, швидким і в той же час достовірним методом, який дозволяє визначити характер захворювання (доброякісний чи злоякісний), гістологічний тип і ступінь диференціювання.

Цитопатологам достеменно відомі цитоморфологічні ознаки різних гістологічних типів РЛ і ступінь їх диференціювання, на які вони опираються під час верифікації патологічного процесу [5-7]. Проте, щоб діагностувати наявність пухлини в цитологічному препараті, необхідно мати інформативний матеріал, який доставляється в лабораторію.

Для цитологічного дослідження при РЛ використовують ексфоліативні матеріали - мазки з екзофітного новоутворення в бронху та лаваж (промивні води бронхів), які отримують під час фібробронхоскопії (ФБС). Результати подібних до- сліджень у різних авторів часто відрізняються. Чутливість цитологічного методу досить висока і при отриманні саме інформативного матеріалу може становити 89-97\%, а специфічність - 79-98\% [5-7].

Морфологічна верифікація РЛ відіграє ключову роль у встановленні діагнозу і вирішенні тактики спеціального лікування хворого. Тому в онкологічний заклад направляють пацієнтів з метою визначення характеру патологічного процесу - доброякісний чи злоякісний. Уже в поліклініці за допомогою цитологічного методу є можливість вирішити це питання способом ексфоліативної чи пункційної цитологічної діагностики.

За необхідності виконують допоміжні імуноцитохімічні та молекулярно-біологічні дослідження, які в ряді випадків сприяють уточненню характеристики клітин, ступеня їх проліферації, виявленню хромосомних аберацій, що дає можливість лікарю вибрати таргетні хіміотерапевтичні препарати в разі консервативного лікування хворого.

Отримання інформативного діагностичного матеріалу під час виконання ФБС залежить від характеру росту і розповсюдження РЛ по слизовій оболонці бронха і в його стінці - ендобронхіально, ендо-перибронхіально та перибронхіально $[8,9]$.

Вважалося логічним, шо в разі отримання мазка з екзофітно розвиненої в бронху пухлини під час виконання ФБС у цитологічному препараті мають бути виявлені пухлинні клітини. Але багато років оцінюючи такий матеріал (мазки з поверхні екзофітно розвиненої пухлини в бронху та промивних вод) ми впевнилися, що в ньому не завжди можна знайти ракові клітини. Цей факт спонукав нас провести окреме спеціальне дослідження зскрібків з екзофітних пухлин у бронхах на операційному матеріалі $[3,10]$ і співставити отримані дані з результатами цитологічної діагностики у разі виконання ФБС-обстеження пацієнтів. 


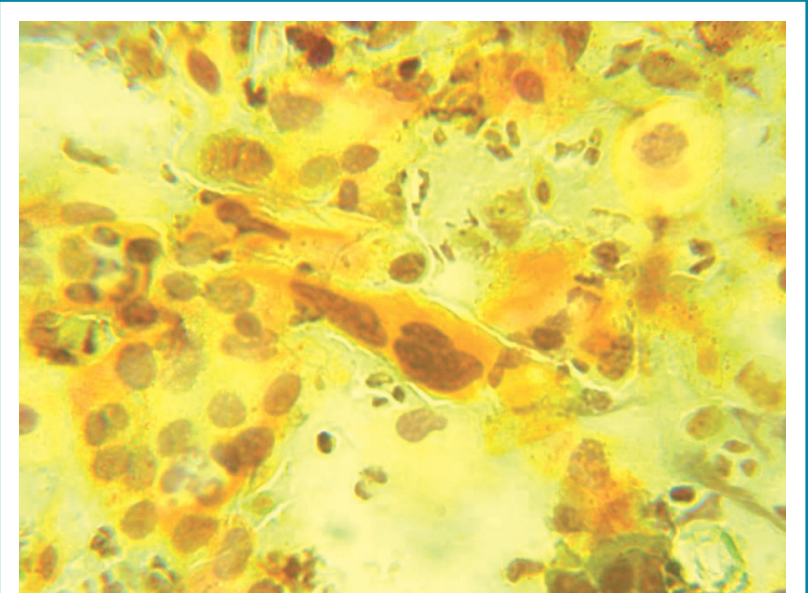

Рис. 1. Плоскоклітинний рак. Забарвлення за Папаніколау, $\times 400$

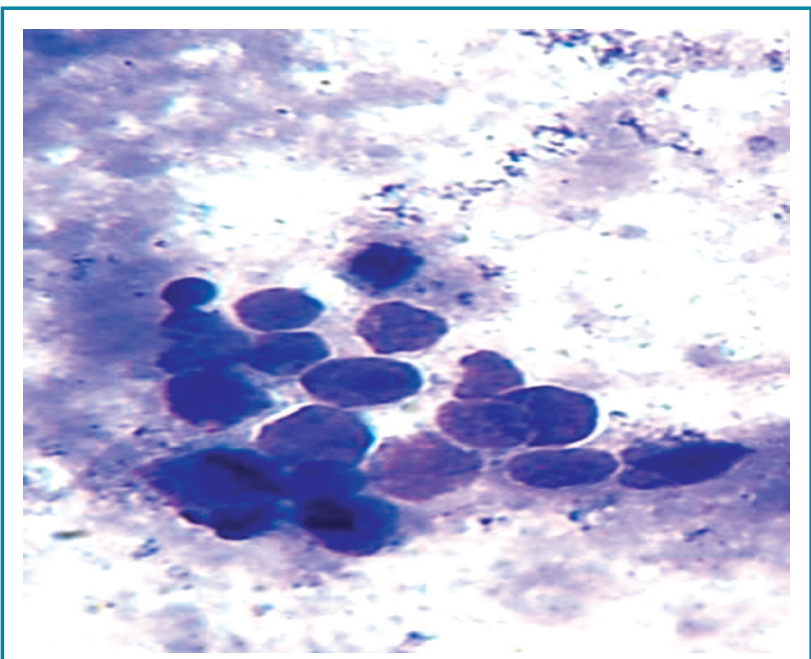

Рис. 3. Дрібноклітинний рак. Забарвлення за Паппенгеймом, $\times 400$

Мета - визначити результати цитологічної діагностики за ексфоліативними матеріалами з бронхів.

\section{МАТЕРІАЛИ I МЕТОДИ ДОСЛІДЖЕННЯ}

Проведено аналіз результатів цитологічної діагностики хворих на РЛ, які обстежувалися і лікувалися в Національному інституті раку у 2016 р. Хворих було направлено в Національний інститут раку з діагнозами: «підозра на РЛ»; «РЛ»; «туберкульоз?»; «метастатичне ураження легені?». Середній вік хворих становив $60,92 \pm 1,14$ року.

ФБС-обстеження виконано у 776 пацієнтів. Обстеження проводилися в поліклінічних умовах. У хворих виявляли центральні і периферичні форми РЛ. Виготовлені цитологічні препарати забарвлювали за методами Паппенгейма та Папаніколау і вивчали за допомогою мікроскопів Olympus CX21, Olympus CX41 та Olympus BX41, при різних збільшеннях: × 100; $\times 200 ; \times 400 ; \times 1000$. Використовували Міжнародну гістологічну класифікацію для визначення гістологічного типу РЛ [11].

РЕЗУЛЬТАТИ ДОСЛІДЖЕННЯ І ЇХ ОБГОВОРЕННЯ

Проведено цитологічні дослідження матеріалу, отриманого під час ФБС-обстеження, у вигляді мазків з ураженої ділянки і промивних вод з бронхів у 776 хворих. 3 них у 195 (25\%) пацієнтів встановлено РЛ різних гістологічних типів, у 24 (3,5\%) - виявлені поодинокі клітини з ознаками атипії, які дозволили цитопатологу зробити висновок про пі-

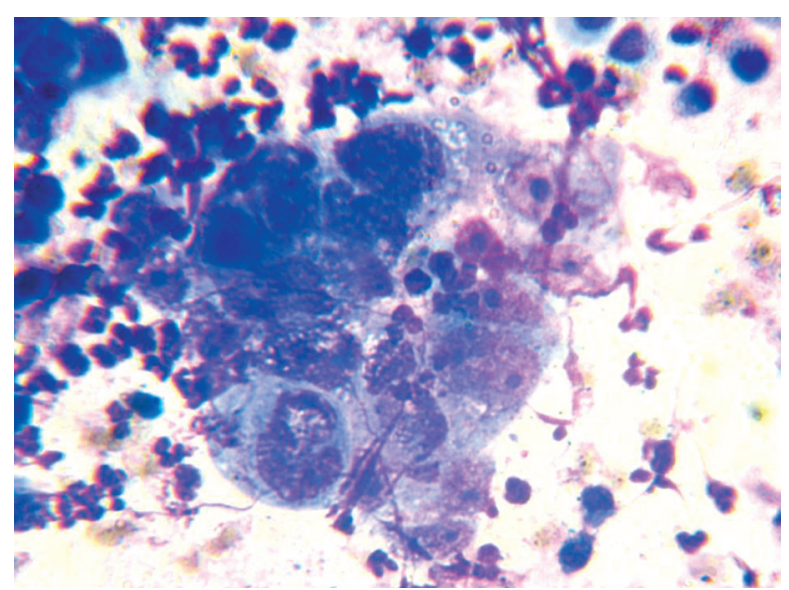

Рис. 2. Аденокарцинома. Забарвлення за Паппенгеймом, $\times 400$

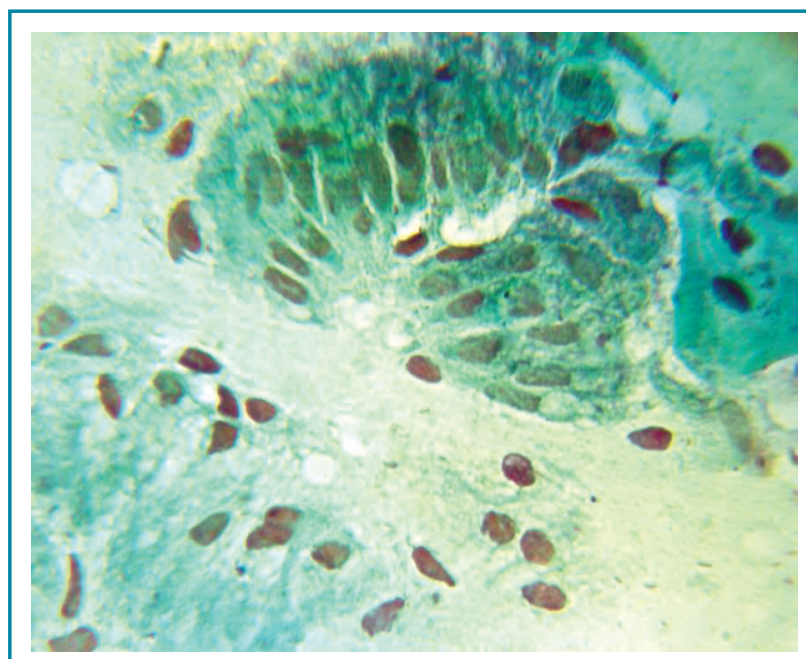

Рис. 4. Циліндричний епітелій. Забарвлення за Папаніколау, $\times 400$

дозру на рак. У 35 (4,5\%) хворих визначено невелику кількість клітин з невираженими ознаками атипії, що обгрунтувало висновок в описовій формі.

У групі хворих з визначеним злоякісним процесом плоскоклітинний рак виявлено у $79(10,2 \%)$ пацієнтів (рис. 1), аденокарциному - у 61 (8\%) (рис. 2). Групу недрібноклітинного раку становили $34(4,4 \%)$ пацієнти. Такий тип висновку свідчить про невиразність цитологічних ознак ні плоскоклітинного, ні залозистого раку, що частіше спостерігається при помірному ступені диференціювання клітин. Крім того, такий термін часто трапляється в багатьох наукових публікаціях вітчизняних і закордонних учених, що дозволяє його використання як загальновизнаний. Серед усіх ракових процесів дрібноклітинний (недиференційований) тип виявлено у 19 (2,4\%) хворих (рис. 3). Цитологічний висновок про наявність злоякісної пухлини без визначення іiі гістогенезу видано у $2(0,3 \%)$ випадках.

Найбільшу групу цитологічних висновків становили описові відповіді - 522 (67\%), у матеріалі яких визначалися клітини циліндричного епітелію з різними ознаками проліферації і дистрофічними змінами (рис. 4).

Результати цитологічних досліджень матеріалів, отриманих під час виконання ФБС, продемонстровані на рис. 5 i 6.

Аналіз результатів цитологічної діагностики за ексфоліативними матеріалами, отриманими під час ФБС-обстеження, свідчить про невисоку його ефективність. Так, серед 776 хворих лише у 195 (25\%) за цитологічними препаратами установ- 


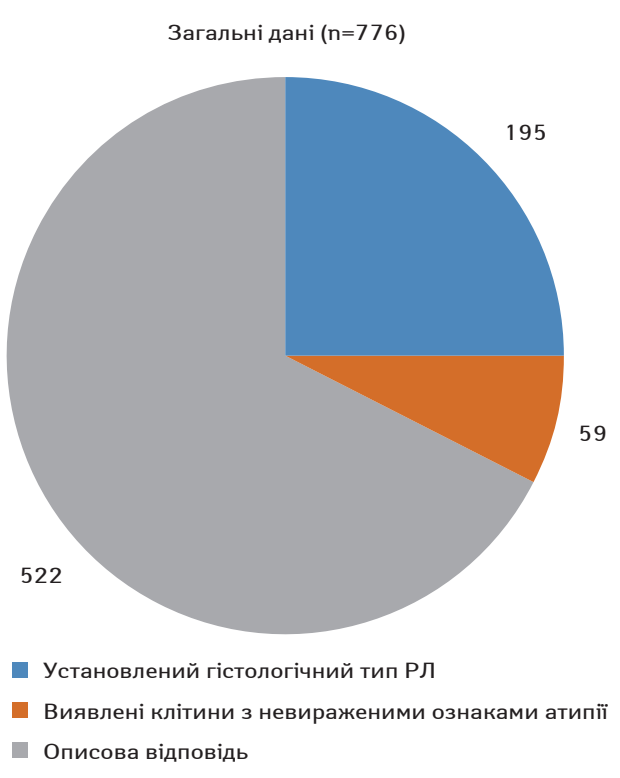

Рис. 5. Загальні результати цитологічної діагностики за ексфоліативними матеріалами

лено гістологічний тип РЛ, у 59 (8\%) виявлено клітини з невираженими ознаками атипії, що дозволило зробити висновок про підозру на РЛ або видати описову відповідь про наявність поодиноких клітин з невираженими ознаками атипії. У той же час у 522 (67\%) хворих у цитологічних препаратах відмічені тільки клітини циліндричного епітелію, який свідчить про цілісність епітеліального покриву бронха.

Займаючись десятиліттями цитологічною діагностикою РЛ, ми не могли зрозуміти той факт, що за наявності екзофітного росту в бронху, який виявляється при ФБС-обстеженні, у цитологічних препаратах при цьому відсутні пухлинні клітини. Як можна пояснити такий стан речей? У науковій літературі не знайдено аргументованої відповіді на це питання.

Це спонукало нас провести окремі спеціальні дослідження поверхні екзофітних пухлин у бронхах на операційному матеріалі. Результати вивчення матеріалу, отриманого з поверхні екзофітних новоутворень у бронхах у 31 хворого, прооперованого з приводу РЛ, показало, що у зскрібках з такої поверхні лише у 9 (28\%) з них можна було отримати пухлинні клітини, а у $22(72 \%)$ - в аналогічних зскрібках - виявити тільки клітини мало зміненого циліндричного епітелію [10]. Це було досить несподівано. Пояснити це явище можна лише тим, шо ракова пухлина легені починає свій розвиток під циліндричним епітелієм і лише з часом проростає його і стає доступною для отримання клітин РЛ для цитологічного дослідження. Встановлений факт $€$ першим ймовірним доказом того, що результати ексфоліативної цитологічної діагностики залежать від рівня вростання РЛ у стінку слизової оболонки іпроростання епітелію, який його вистиляє.

\section{ВИСНОВКИ}

Таким чином, виявлений нами достовірний факт залежності результатів ексфоліативної цитологічної діагностики від проростання раковою пухлиною стінки бронха з його слизовою оболонкою до цього часу не мав відображення в літературі.

Результати проведених цитологічних досліджень на операційному [10] і поточному діагностичному матеріалі дають підстави стверджувати, що морфологічна верифікація РЛ за ексфоліативним матеріалом можлива лише в 28-33\%, що обумовлено ступенем проростання пухлиною стінки і слизової оболонки бронха. Подальша верифікація РЛ має базуватися на прицільному отриманні пункційного діагностичного матеріалу.

Визначення характеру росту РЛ залежно від взаємодії зі слизовою оболонкою бронха має пряме відношення до по-

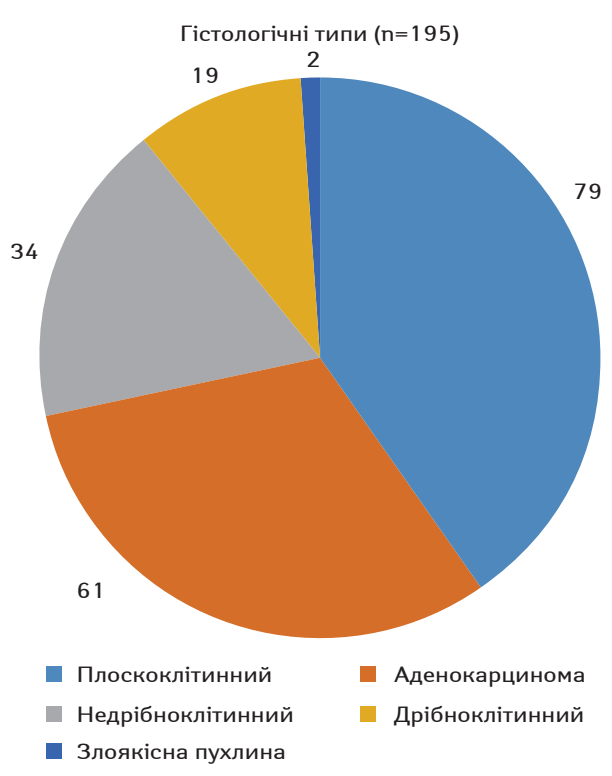

Рис. 6. Гістологічні типи РЛ, установлені за ексфоліативними матеріалами

дальшого всебічного вивчення гістогенезу РЛ, що є надзвичайно важливим напрямком у перспективному розвитку фундаментальної і прикладної онкоморфології і онкопульмонології.

\section{СПИСОК ВИКОРИСТАНОЇ ЛІТЕРАТУРИ}

1. Sung, H., Ferlay, J., Siegel, R. L., Laversanne, M., Soerjomataram, I., Jemal, A. \& Bray, F. (2021) Global Cancer Statistics 2020: GLOBOCAN Estimates of Incidence and Mortality Worldwde for 36 Cancers in 185 Countries. CA: A Cancer Journal for Clinicians, 71(3), 209-249. doi: 10.3322/caac.21660.

2. Федоренко, З. П., Михайлович, Ю. Й., Гулах, Л. О., Горох, Є. Л., Рижов, А. Ю., Сумкіна, О. В., \& Куценко, Л. Б. (2021). Рак в Україні 2019-2020 рр.: Захворюваність, смертність, показники діяльності онкологічної служби. Бюлетень Національного Канцер-реєстру України. Київ. Поліум.

3. Bеєтру Країни. Киї. Полім. $\mathrm{N}$ Alekseenko, O L., Letvinets, O. M. Suprun, G. A., \& Ponomarenko, A. A. (2020). Histogenesisof central lung cancer: cytologican investigation. Experimental oncology, 42(4), 310-313. doi: 10.32471/exp-oncology.2312-8852.vol-42-no-4.15232.

4. Шапиро, Н. А. (2008). Принципы цитологической диагностики злокачественных опухолей. Т. З. Москва: Медицина.

5. Мельник, А. Н. (1983). Цитоморфологическая диагностика опухолей. Киев: Здоров'я.

6. Петрова, А. С. (1985). Цитологическая диагностика предопухолевых и опухолевых процессов. Москва: Медицина.

7. Шапиро, Н.А.(2005). Цитологическая диагностика заболеваний легких. Т. 2. Москва: Медицина.

8. Болгова, Л. С., \& Туганова, Т. Н. (2013). Рак легкого: вопросы гистогенеза и цитологической диагностики. Киев: КИМ.

9. Болгова, Л. С., \& Пономаренко, А. О. (2020). Особливості росту периферичного раку легені за результатами макроскопічнихі цитологічнихдосліджень. Наукові записки НаУКМА, 3, 43-47. doi:10.18523/2617-4529.2020.3.43-47.

10. Bolgova, L., Tuganova, T., \& Ponomarenko, A. (2021). Cytological research of exophytic tumors of the bronchi and the grow pattern of lung cancer. Наукові записки НаУKMA, 4, 26-31. doi:10.18523/2617-4529.2021.4.26-31.

11. Travis, W. D., Brambilla, E., Burke, A. P., Marx, A., \& Nicholson, A. G. (2015). WHO Classification of Tumours. Pathology and genetics of Tumours of the Lung, Pleura, Thymus and Heart. NY: IARC Press.

Possibilities of exfoliative cytological diagnostics depending on the growth pattern of lung cancer

L.S. Bolgova, T.M. Tuganova, O.I. Alekseenko, T.M. Yaroshchuk, M.G. Makhortova, E.O. Loginova, S.V. Marinenko, G.O. Suprun, N.V. Bogonis

National Cancer Institute, Kyiv

Abstract. Introduction. Lung cancer (LC) is the most frequent oncological disease in the world and Ukraine. The high mortality rate from it also persists. Treatment of LC is prescribing only after morphological (cytological or histological) verification. The first step on the way to clarify the nature of the pathological process in the lung is a cytological examination of the material (smears and bronchial washings) obtained by performing flexible bronchoscopy. The aim of our study was to analyze the results of cytological diagnostics using exfoliative material. Materials and methods. The analysis of the results of cytological diagnostics obtained 


\section{Оригінальні статті / Original Articles}

by flexible bronchoscopy in 776 patients who were examined and treated at the National Cancer Institute in 2016 was carried out. The average age of the patients was $(60.92 \pm 1.14)$. The preparations were stained according to the Pappenheim and Papanicolaou methods. Results and discussion. The histological type of LC was established in $195(25 \%)$, in $24(3.5 \%)$ - a suspicion of LC was expressed in the cytological report, in 35 (4.5\%) patients a descriptive type of cytological conclusion was observed. The largest group consisted of $522(67 \%)$ patients, in whose cytological preparations only the cylindrical epithelium was detected, that is, the unchanged lining epithelium of the bronchial mucosa was identified. This fact justified the need to compare the data obtained with the results of the surgical material (scrapings of the surface of exophytic tumors in the bronchus were carried out), which made it possible to identify cancer cells in 9 (28\%) of 31 patients, in the rest $-22(72 \%)-$ only cells of the cylindrical epithelium. Conclusions. The fact that we have established that the results of exfoliative cytological diagnostics depend on the proliferation of LC of the bronchial mucosa, which has not yet been presented in the special literature.
The results of the study allow us to state that exfoliative cytological diagnostics is possible in $28 \%-33 \%$ of cases and depends on the degree of tumor invasion in to the bronchial mucosa. The revealed growth of LC under the bronchial mucosa is directly relate do the further study of LC histogenesis, which is an important aspect in the future development of fundamental and applied oncomorphology and oncopulmonology.

Key words: growth of lung cancer; exfoliative cytological diagnostics.

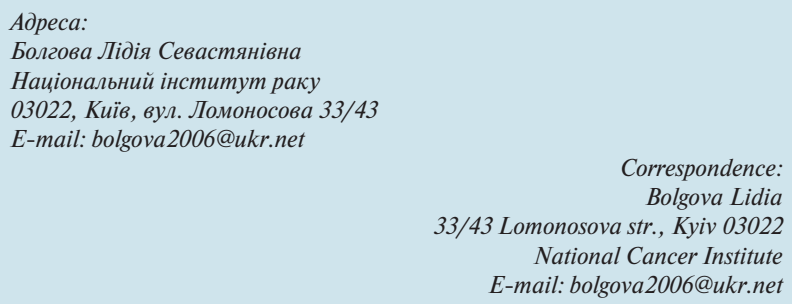

E-mail:bolgova2006@ukr.net

Correspondence: Bolgova Lidia 33/43 Lomonosova str., Kyiv 03022 National Cancer Institute E-mail:bolgova2006@ukr.net 